DOI: 10.17707/AgricultForest.63.1.09

\begin{abstract}
Anatoly SMYKOV, Yuriy IVASHCHENKO, Iuliia IVASHCHENKO, Olga FEDOROVA ${ }^{I}$
\end{abstract}

\title{
PHOTOSYNTHETIC ACTIVITY OF PEACH LEAF IN CONNECTION WITH DROUGHT TOLERANCE
}

\section{SUMMARY}

The aim of our research was to study the leaf chlorophyll fluorescence parameters of peach and selection of cultivars with increased resistance to drought. Studies were conducted in the laboratory on intact leaf plates of 8 cultivars of foreign selection (Veteran, Zempush, Gavazuri, Tszyu-Yus-Tszyuy, Hidistavsky Belyiy, Baby Gold-7, Pintu, Favorita Morettini) in two periods August and September. The control cultivar was Kryimsky Shedevr of Nikitska Botanical Garden selection.

Photosynthetic activity was characterized by chlorophyll fluorescence parameters (Kautsky effect). It was established that, as a result of 24-hour water deficit parameter, Fm operates more stable in cultivars Hidistavsky Belyiy, Tszyu-Yus-Tszyuy and Baby Gold-7. More prone to dehydration were peach cultivars Zempush and Pintu. Suppression index have reached 21-22\%. High stability parameter Fm combined with a high water-holding capacity was found in grade Tszyu-Yus-Tszyuy. The leaves of this cultivar have lost least amount of moisture by dehydration $(45 \%)$. On an indicator of $\left(\mathrm{F}_{\mathrm{m}}-\mathrm{F}_{0}\right) / \mathrm{F}_{\mathrm{m}}$ the highest value was recorded in cultivar Pintu. Cultivars Pintu, Gavazuri and Tszyu-Yus-Tszyuy are the best according to the indicators $\left(\mathrm{F}_{\mathrm{m}}-\mathrm{F}_{\mathrm{st}}\right) / \mathrm{F}_{\mathrm{m}}$ and $\left(\mathrm{F}_{\mathrm{m}} / \mathrm{F}_{\mathrm{st}}\right)$. Their photoactivity is $10-12 \%$ higher in comparison with other cultivars and control cultivar Kryimsky Shedevr. They are characterized by a high water-holding capacity and a significant degree of recovery turgidity of tissues (82-100\%). Cultivars Hidistavsky Belyiy, Veteran are promising for further study. Some cultivars have a high photoactivity at various stages of photosynthesis (Zempush, Baby Gold-7), indicating a wide range of applications in order to diagnose the state of the photosynthetic apparatus in fluorimetry method of dehydration of the leaves.

Keywords: Peach, cultivars, drought resistant, parameters fluorescence

\section{INTRODUCTION}

Peaches (Persica vulgaris Mill.) - one of the most popular fruit crops in the south of Russia. This is due to its early appearance of fruit, high yield

\footnotetext{
${ }^{1}$ Anatoly Smykov (corresponding author: fruit_culture@mail.ru), Yuriy Ivashchenko, Iuliia Ivashchenko, Olga Fedorova Nikita Botanical Gardens - Federal Reseach Centre of RAS, Yalta, RUSSIAN FEDERATION

Paper presented at the $7^{\text {th }}$ International Scientific Agricultural Symposium "AGROSYM 2016".

Notes: The authors declare that they have no conflicts of interest. Authorship Form signed online.
} 
potential, outstanding flavor, dietary and medicinal properties of fruits, their suitability for different types of processing. Crimea refers to insufficient moisture zone with a large deficit of irrigation water in the summer, so the creation of new drought-resistant varieties - a very important issue for the development of peach culture.

The parameters of the water regime, which determine the degree of drought resistance, are closely related to leaf apparatus performing photosynthesis function. Violation of the functional state of the photosynthetic apparatus, which occurs under the influence of the arid conditions of the environment, expressed in leaf tissue damage and reduced yields of peach trees (Smykovet al., 2001; Kershanskaya, 2007; Ivashchenko, 2008).

Photosynthesis and fluorescence are interrelated processes and reflect the efficiency of the distribution of the absorbed light energy (Bilgeret al., 1990). Disturbances in the process of photosynthesis, cause characteristic changes in the fluorescence intensity: the less energy used in photochemical processes, the higher the level of fluorescence (Brionet al., 2000; Stirbet, 2011.).

The study of photosynthetic processes based on the phenomenon of fluorescence allows to estimate the resistance of plants to drought at the subcellular level, operation of the of chlorophyll-protein complexes under the action of high temperatures, insufficient moisture and wind drying up in the summer.

It is also important in practical and methodical purposes to establish the influence of a complex of conditions that lead to a deficiency of moisture in the tissues of the leaf plates, on photoactivity of a leaf.

The aim of our study was to investigate the influence of extreme conditions of summer period to the change of chlorophyll fluorescence parameters of peach leaves and selection of cultivars with improved drought tolerance.

\section{MATERIALS AND METHODS}

Studies conducted in laboratory conditions on intact leaf plates of 8 peach cultivars (Veteran, Zempush, Gavazuri, Tszyu-Yus-Tszyuy, Hidistavsky Belyiy, Baby Gold-7, Pintu, Favorita Morettini) different ecological and geographical origin. The plants grew on peach collection sites of Nikita Botanical Garden, Yalta, Crimea. Samples of leaves were collected in the first week of August and September 2015. During the research observed hydrothermal stress in plants peach. The average daily air temperature was $27.7^{\circ} \mathrm{C}$ (August) and $28.5^{\circ} \mathrm{C}$ (September), which is $4.3-5.1{ }^{\circ} \mathrm{C}$ above normal, the maximum reached $-35.6{ }^{\circ} \mathrm{C}$ (Table 1).

Air humidity decreased to $20 \%$ and $28 \%$. During the first week were fell $7.9 \mathrm{~mm}$ precipitation in August and $24.8 \mathrm{~mm}$ - in September. The reserves of productive moisture in a meter layer of soil under the peach amounted to 26 and $25 \mathrm{~mm}$. Maximum soil surface temperature was raised to $58^{\circ} \mathrm{C}$ and $56.2^{\circ} \mathrm{C}$. 
Table 1.Agrometeorological parameters of the experiment in August-September, Yalta, 2015.

\begin{tabular}{|c|c|c|}
\hline \multirow{2}{*}{ Agrometeorological parameters } & August & September \\
\cline { 2 - 3 } & the first week & $\begin{array}{c}\text { the first } \\
\text { week }\end{array}$ \\
\hline The average air temperature & $27.7^{\circ} \mathrm{C}$ & $28.5^{\circ} \mathrm{C}$ \\
\hline The maximum air temperature & $35.6^{\circ} \mathrm{C}$ & $34.8^{\circ} \mathrm{C}$ \\
\hline The amount of rainfall & $7.9 \mathrm{~mm}$ & $24.8 \mathrm{~mm}$ \\
\hline Minimum humidity & $20.0 \%$ & $28.0 \%$ \\
\hline Maximum temperature of the soil & $58.0^{\circ} \mathrm{C}$ & $56.2^{\circ} \mathrm{C}$ \\
\hline $\begin{array}{c}\text { The stock of productive moisture in } \\
\text { a meter layer of soil }\end{array}$ & $26.0 \mathrm{~mm}$ & $25.0 \mathrm{~mm}$ \\
\hline
\end{tabular}

Indicators of the water content in the leaves, the moisture loss in the course of wilting and ability to restore turgor determined according to generally accepted guidelines (Lishchuk et al., 1991, 1999). Changes in fluorescence intensity were carried out on a portable fluorometer "Floratest". Leaves were taken in triplicate of each cultivar and before measuring fluorescence parameters adapted to the dark for 8 minutes. In the spectral range of operation of photosynthetically active forms of chlorophyll $(690 \mathrm{~nm})$ was recorded multicomponent photo induction fluorescence curve (Kautsky effect), which proved to be very informative in studying drought resistance of peach plants (Buschmann, 1986; Krause, Weis, 1991). We used the following parameters: $\mathrm{F}_{0}$ - background or a minimum fluorescence level excited by very low intensity of measuring light to keep PS II reaction centers open; $\mathrm{F}_{\mathrm{m}}$ - maximum fluorescence level meets both the beginning of producing photosynthetic processes, $\mathrm{CO}_{2}$ fixation and activation of enzymes of the Calvin cycle; $\mathrm{F}_{\mathrm{st}}-$ stationary level of fluorescence, indicating on establishing a stable and most intense level of photosynthesis; $F_{v}$ - variable fluorescence, corresponding to the difference between the maximum and minimum levels $\left(\mathrm{F}_{\mathrm{m}}-\mathrm{F}_{\mathrm{o}}\right)$, which determines the ability of the chlorophyll apparatus to the photosynthesis; $F_{v} / F_{o}-$ the parameter has been related tothe maximum and effective photochemical quantum yield of PSII; $\left(\mathrm{F}_{\mathrm{m}}-\mathrm{F}_{\mathrm{st}}\right) / \mathrm{F}_{\mathrm{m}}-$ coefficient of fluorescence induction; $\mathrm{F}_{\mathrm{m}} / \mathrm{F}_{\mathrm{st}}$ - fluorescence decrease rate (Brion et al., 2000; Korneev., 2002). Changing the photoactivity of the studied cultivars were presented in comparison with the control cultivar Kryimsky Shedevr of Nikitska Botanical Garden selection.

\section{RESULTS AND DISCUSSION}

The photosynthetic activity of the leaves is made up of a number of different quality stages of photosynthesis. Usually the steps forming of the primary processes of photosynthesis, including capture or absorption of light energy of pigment-protein complexes (parameter $\mathrm{F}_{\mathrm{m}}$ ), the transfer of energy to the primary electron acceptors, which characterizes the efficiency index $\left(\mathrm{F}_{\mathrm{m}}-\right.$ $\left.\left.\mathrm{F}_{0}\right) / \mathrm{F}_{\mathrm{m}}\right)$. 
Table 2. Change of leaf fluorescence indicators of introduced cultivars of peach in different conditions of water regime, August 2015.

\begin{tabular}{|c|c|c|c|c|c|c|c|c|c|}
\hline \multirow{2}{*}{$\begin{array}{l}\text { Peach cultivars, } \\
\text { the conditions of the } \\
\text { water regime }\end{array}$} & \multicolumn{6}{|c|}{$\begin{array}{l}\text { Changes in fluorescence indicators } \\
\text { rel. un }\end{array}$} & \multirow{2}{*}{ 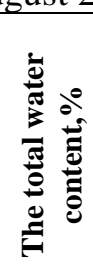 } & \multirow{2}{*}{ 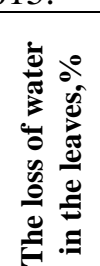 } & \multirow{2}{*}{ 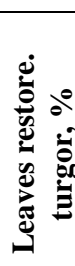 } \\
\hline & $\mathrm{F}_{0}$ & $\mathrm{~F}_{\mathrm{m}}$ & $\mathrm{F}_{\mathrm{st}}$ & $\mathrm{F}_{\mathrm{v}}$ & $\underline{\mathrm{F}_{\mathrm{m}}-\mathrm{F}_{\mathrm{st}}} \overline{\mathrm{F}}_{\mathrm{m}}$ & $\underline{\mathrm{F}}_{\mathrm{m}}$ & & & \\
\hline \multicolumn{10}{|c|}{ Kryimsky Shedevr (control) } \\
\hline After saturation & 485 & 2085 & 507 & 1600 & 1.01 & 4.11 & & & \\
\hline After 24h moisture loss & 592 & 1493 & 1184 & 901 & 0.21 & 1.26 & 46.7 & 52.6 & \\
\hline $\begin{array}{l}\text { After the restoration } \\
\text { of turgor }\end{array}$ & 352 & 544 & 384 & 192 & 0.29 & 1.42 & & & 63.5 \\
\hline \multicolumn{10}{|c|}{ Veteran } \\
\hline Afte & 421 & 1723 & 475 & 1302 & 0.72 & 3.63 & & & \\
\hline After 24h moisture loss & 485 & 1195 & 1045 & 710 & 0.13 & 1.14 & 49.0 & 54.2 & \\
\hline $\begin{array}{l}\text { After the restoration } \\
\text { of turgor }\end{array}$ & 475 & 1398 & 712 & 689 & 0.49 & 1.96 & & & 55.0 \\
\hline \multicolumn{10}{|c|}{ Zempush } \\
\hline After saturation & 475 & 2229 & 528 & 1754 & 0.76 & 4.22 & & & \\
\hline After 2 & 736 & 1765 & 1029 & 1029 & 0.41 & 1.72 & 49.0 & 48.9 & \\
\hline $\begin{array}{l}\text { After the restoration } \\
\text { of turgor }\end{array}$ & 528 & 2224 & 512 & 1696 & 0.77 & 4.34 & & & 60.0 \\
\hline \multicolumn{10}{|c|}{ Tszyu-Yus-Tszyuy } \\
\hline Afte & 459 & 2213 & 576 & 1754 & 0.74 & 3.84 & & & \\
\hline After 24h moisture loss & 667 & 1963 & 832 & 1296 & 0.58 & 2.36 & 50.0 & 44.8 & \\
\hline $\begin{array}{l}\text { After the restoration } \\
\text { of turgor }\end{array}$ & 640 & 1973 & 667 & 1333 & 0.66 & 2.96 & & & 97.5 \\
\hline \multicolumn{10}{|c|}{ Hidistavsky Belyiy } \\
\hline & 592 & 2277 & 603 & 1685 & 0.74 & 3.78 & & & \\
\hline After 2 & 693 & 2186 & 1472 & 1493 & 0.33 & 1.49 & 48.6 & 49.9 & \\
\hline $\begin{array}{l}\text { After the restoration of } \\
\text { turgor }\end{array}$ & 673 & 1973 & 709 & 1300 & 0.64 & 2.78 & & & 85.0 \\
\hline \multicolumn{10}{|c|}{$\frac{1}{\text { Pintu }}$} \\
\hline After satur & 456 & 2336 & 552 & 1880 & 0.76 & 4.23 & & & \\
\hline After 24h moisture loss & 768 & 2976 & 795 & 2208 & 0.73 & 3.74 & 54.2 & 49.6 & \\
\hline $\begin{array}{l}\text { After the restoration of } \\
\text { turgor }\end{array}$ & 564 & 2399 & 603 & 1834 & 0.75 & 3.97 & & & 100.0 \\
\hline \multicolumn{10}{|c|}{ Baby Gold-7 } \\
\hline After & 459 & 1920 & $475^{\circ}$ & 1461 & 0.75 & 4.04 & & & \\
\hline After 24h moisture loss & 565 & 1664 & 1221 & 1099 & 0.27 & 0.27 & 43.8 & 50.8 & \\
\hline $\begin{array}{l}\text { After the restoration of } \\
\text { turgor }\end{array}$ & 389 & 1227 & 796 & 741 & 0.35 & 1.54 & & & 48.0 \\
\hline \multicolumn{10}{|c|}{ Favorita Morettini } \\
\hline ion & 395 & 1637 & 405 & 1242 & 0.75 & 4.04 & & & \\
\hline After 24h moisture loss & 581 & 1211 & 1034 & 630 & 0.15 & 1.17 & 42.7 & 58.8 & \\
\hline $\begin{array}{l}\text { After the restoration of } \\
\text { turgor }\end{array}$ & 467 & 1104 & 537 & 637 & 0.51 & 2.05 & & & 43.0 \\
\hline
\end{tabular}


Further processes determining the photoactivity associated with the functioning of the dark, photochemical reactions of photosynthesis (index $\left(\mathrm{F}_{\mathrm{m}}\right.$ $\left.\mathrm{F}_{\mathrm{st}}\right) / \mathrm{F}_{\mathrm{m}}$ ), and conjugation processes of absorption and transmission of light energy to process of disposal $\left(\mathrm{F}_{\mathrm{m}} / \mathrm{F}_{\mathrm{st}}\right)$. For leveling conditions of wilting the leaf blade applied approach proposed by Lishchuk et al. consisting in complete saturation of the material up to $100 \%$ humidity. In the process of the research revealed that the leaves of studied varieties in 24 hours of wilting lost by 42.7 to $54.2 \%$ of moisture. Under these parameters, moisture loss, restoring turgor of leaves ranged from $43.0 \%$ (Favorita Morettini) to $100.0 \%$ (Pintu).

Table 2. presents data on changes in indicators photoactivity introduced cultivars of peach (fluorometric indicators and their ratio) under different drainage regimes. From 8 introduced cultivars of peach belonging to different ecotypes, were identified in a row of promising indicators of photoactivity.

Comparative analysis of the value of the pool complexes of light trapping $\left(\mathrm{F}_{\mathrm{m}}\right)$, shows that the cultivar characteristics are appear significantly. Light trapping structure of the most stable functioning the varieties Hidistavsky Belyiy, Tszyu-Yus-Tszyuy and Baby Gold-7. As a result of 24 hours of dehydration they occurred the decline of index within the $4-13 \%$. The greatest decrease $F_{m}$, within the limits of 21-22\% was observed in cultivars Zempush and Pintu.

A strong dehydration and unstable functioning of light trapping complexes appeared in the cultivars Kryimsky Shedevr, Favorita Morettini and Veteran. In the cultivar Kryimsky Shedevr observed decline $\mathrm{F}_{\mathrm{m}}$ by $28 \%$ Favorita Morettini by $26 \%$ at the cultivar Veteran by $30 \%$. More importantly these cultivars is reduced variable fluorescence $\left(\mathrm{F}_{\mathrm{v}}\right)$. In conditions of dewatering its index decreased by $44-49 \%$.In the context of itsof dehydration performance decreased by $44-49 \%$. Within 24 hours of dehydration leaves of cultivars Kryimsky Shedevr, Favorite Morettini and Veteran also lost more than half of the original moisture content of the leaf. Less significant was the recovery in turgor characterized cultivars (43-64\%). It should be noted that the cultivars of leaves Favorita Morettini after dehydration regained turgor just $43 \%$. This is $20 \%$ less than that of the control cultivar Kryimsky Shedevr but photoactivity indicators reduce to 2 times better than the control cultivar. According to the cultivar characteristics, high stability of operation of light-harvesting complexes $\left(\mathrm{F}_{\mathrm{m}}\right)$, distinguished cultivar Tszyu-Yus-Tszyuy. The leaves of this cultivar have lost an average of 1.3 times less moisture than cultivar weakly resistant to dehydration. The same trend was observed in relation to the indicator variable fluorescence $\left(F_{v}\right)$ and others available to us for research parameters $-\left(\mathrm{F}_{\mathrm{m}}-\mathrm{F}_{\mathrm{st}}\right) / \mathrm{F}_{\mathrm{m}}$ and $\mathrm{F}_{\mathrm{m}} / \mathrm{F}_{\mathrm{st}}$.

These indicators reflect the effectiveness of the passage of the primary processes of photosynthesis and the level of transformation of light energy into photochemical reactions of the chloroplast membrane systems. It can be assumed that a disturbance of the primary processes of photosynthesis and whole photoactivity as a result of dehydration leaf plate reaches the small size of cultivars Pintu (reduction of 10\%), Hidistavsky Belyiy (29\% reduction) and Tszyu-Yus-Tszyuy (reduction of 29\%). 
A more significant change in dehydration indicators of photoactivity was obtained from cultivars Kryimsky Shedevr, Veteran, Favorita Morettini (reduction of 64-67\%). How to appear differences between cultivars can be seen in Figure 1, which shows a disturbance of the kinetics of photo induction fluorescence curves (Kautsky effect) native peach leaves as a result of changes in the water regime.

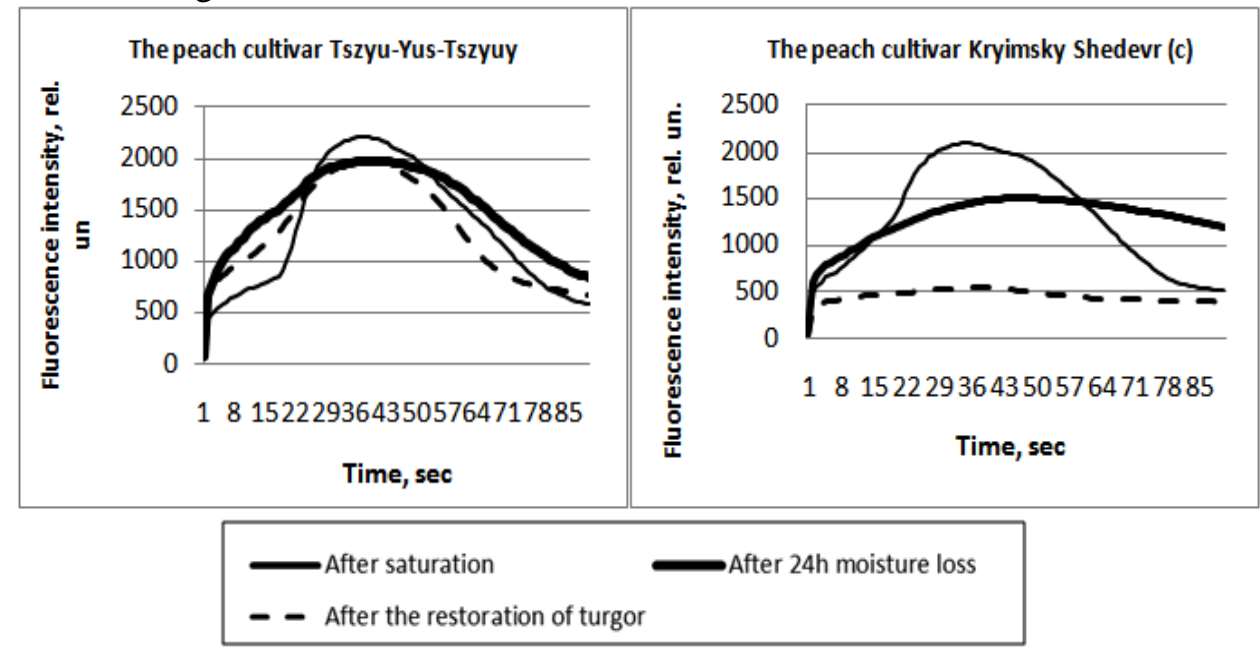

Figure 1.Kinetics photo induction curve of the Kautsky effect in the cultivars of peach Kryimsky Shedevr (control) and Tszyu-Yus-Tszyuyas a result of different conditions of water regime of leaf plates, August, 2015.

Kinetics photoinduction curve reflects all the stages of the primary processes of photosynthesis (Lichtenthaler, 1992) and is a reliable and proven tool to assess plant photoactivity. Photo induction curve at cultivar Tszyu-YusTszyuynon monotonically at all stages of the water regime, but changing its kinetics insignificant. The sharp decrease in the fluorescence intensity and the disturbance of the kinetics of the curve in a state of dehydration and restore turgor leaf plate is fixed at cultivar Kryimsky Shedevr.

These results allow a more objective divided peach cultivars in their sensitivity to waters carcity. Dehydration of the leaf blade results to repression of photoactivity in all stages of the primary photosynthesis. Research foliage photoactivity conducted with the involvement of promising cultivars (Gavazuri) in the first ten days of September, also showed the susceptibility of the lightharvesting complex as a result of dehydration (Table 3).

Loss of moisture in the leaves of the most cultivars was in 8 hours -23 to $35 \%$, in 24 hours -40 to $51 \%$. The leaves, when saturated with water, restored turgor from 42 to $100 \%$. Cultivars were identified with high water-holding capacity: Gavazuri and Pintu (95 and $100 \%$, respectively), which is significantly higher than the control cultivar Kryimsky Shedevr. In terms of the water regime of the leaves (the degree of dehydration when wilting, restoring turgor) Gavazuri cultivar were the most hardy, Pintu and Veteran. 
Table 3.The change in the fluorescence indices of the leaves of introduced peach varieties in different conditions of water regime, September 2015

\begin{tabular}{|c|c|c|c|c|c|c|c|c|c|}
\hline \multirow{2}{*}{$\begin{array}{l}\text { Peach cultivars, } \\
\text { the conditions of the } \\
\text { water regime }\end{array}$} & \multicolumn{6}{|c|}{$\begin{array}{c}\text { Changes in fluorescence indicators } \\
\text { rel. un }\end{array}$} & \multirow{2}{*}{ 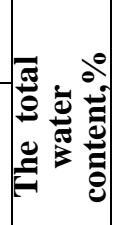 } & \multirow{2}{*}{ 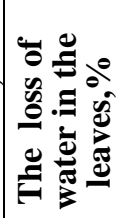 } & \multirow{2}{*}{ 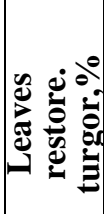 } \\
\hline & $\mathrm{F}_{0}$ & $\mathrm{~F}_{\mathrm{m}}$ & $\mathrm{F}_{\mathrm{st}}$ & $\frac{\mathrm{F}_{\mathrm{V}}}{\mathrm{F}_{0}}$ & $\frac{\mathrm{F}_{\mathrm{m}}-\mathrm{F}_{\mathrm{st}}}{\mathrm{F}_{\mathrm{m}}} \mid$ & $\overline{\mathrm{F}}_{\mathrm{m}}^{\underline{\mathrm{v}}}$ & & & \\
\hline \multicolumn{10}{|c|}{ Kryimsky Shedevr (control) } \\
\hline To saturation & 379 & 1813 & 565 & 3.8 & 0,69 & 0.8 & & & \\
\hline After saturation & 389 & 1632 & 464 & 2.9 & 0,72 & 0.7 & 100.0 & & \\
\hline After 8h moisture loss & 475 & 1984 & 512 & 3.2 & 0,74 & 0.8 & 75.9 & 33.0 & \\
\hline $\begin{array}{c}\text { After 24h } \\
\text { moisture loss }\end{array}$ & 501 & 1243 & 901 & 1.5 & 0,27 & 0.6 & 55.2 & 49.3 & \\
\hline $\begin{array}{l}\text { After the restoration } \\
\text { of turgor }\end{array}$ & 293 & 475 & 347 & 0.6 & 0,27 & 0.4 & & & 42.0 \\
\hline \multicolumn{10}{|c|}{ Gavazuri } \\
\hline To saturation & 325 & 1509 & 443 & 3.6 & 0,71 & 0.8 & & & \\
\hline After saturation & 395 & 1728 & 475 & 3.4 & 0,73 & 0.8 & 100.0 & & \\
\hline After 8h moisture loss & 421 & 1552 & 555 & 2.7 & 0,64 & 0.7 & 85.0 & 22.5 & \\
\hline $\begin{array}{c}\text { After 24h } \\
\text { moisture loss }\end{array}$ & 352 & 1168 & 427 & 2.3 & 0,63 & 0.7 & 62.5 & 39.6 & \\
\hline $\begin{array}{c}\text { After the restoration } \\
\text { of turgor }\end{array}$ & 421 & 1552 & 555 & 2.7 & 0,64 & 0.7 & & & 94.5 \\
\hline \multicolumn{10}{|c|}{ Zempush } \\
\hline To saturation & 672 & 2912 & 848 & 3.3 & 0,71 & 0.8 & & & \\
\hline After saturation & 656 & 2896 & 747 & 3.4 & 0,74 & 0.8 & 100.0 & & \\
\hline After $8 \mathrm{~h}$ moisture loss & 656 & 2891 & 747 & 3.4 & 0,74 & 0.8 & 72.1 & 34.8 & \\
\hline $\begin{array}{c}\text { After } 24 \mathrm{~h} \\
\text { moisture loss }\end{array}$ & 885 & 1701 & 1370 & 0.9 & 0,19 & 0.5 & 47.5 & 50.7 & \\
\hline $\begin{array}{l}\text { After the restoration } \\
\text { of turgor }\end{array}$ & 475 & 1057 & 587 & 1.2 & 0,44 & 0.6 & & & 60.0 \\
\hline \multicolumn{10}{|c|}{ Pintu } \\
\hline To sa & 501 & 2651 & 677 & 4.3 & 0,74 & 0.8 & & & \\
\hline After & 565 & 2656 & 699 & 3.7 & 0,74 & 0.8 & 100.0 & & \\
\hline After $8 \mathrm{~h}$ moisture loss & 634 & 2624 & 683 & 3.1 & 0,74 & 0.8 & 73.6 & 29.9 & \\
\hline After $24 \mathrm{~h} \mathrm{n}$ & 603 & 1861 & 901 & 2.1 & 0,52 & 0.7 & 52.8 & 43.4 & \\
\hline $\begin{array}{l}\text { After the restoration } \\
\text { of turgor }\end{array}$ & 507 & 1760 & 571 & 2.5 & 0,68 & 0.7 & & & 100.0 \\
\hline \multicolumn{10}{|c|}{ Veteran } \\
\hline To saturation & 397 & 1877 & 539 & 3.8 & 0,71 & 0.8 & & & \\
\hline After s & 421 & 1872 & 560 & 3.5 & 0,70 & 0.8 & 100.0 & & \\
\hline After $8 \mathrm{~h}$ moisture loss & 432 & 1696 & 475 & 2.9 & 0,72 & 0.7 & 77.1 & 32.9 & \\
\hline After 24h moisture loss & 475 & 1520 & 731 & 2.2 & 0,50 & 0.7 & 56.3 & 46.3 & \\
\hline $\begin{array}{l}\text { After the restoration } \\
\text { of turgor }\end{array}$ & 379 & 1163 & 485 & 2.1 & 0,58 & 0.7 & & & 82.5 \\
\hline \multicolumn{10}{|c|}{ Hidistavsky Belyiy } \\
\hline To saturation & 565 & 2805 & 715 & 4.0 & 0,75 & 0.8 & & & \\
\hline After saturation & 667 & 3045 & 768 & 3.6 & 0,75 & 0.8 & 100.0 & & \\
\hline After $8 \mathrm{~h} \mathrm{r}$ & 688 & 2805 & 688 & 3.1 & 0,76 & 0.8 & 76.5 & 31.8 & \\
\hline $\begin{array}{l}\text { After } 24 \mathrm{~h} \\
\text { moisture loss }\end{array}$ & 725 & 2181 & 1221 & 2.0 & 0,44 & 0.7 & 47.1 & 50.8 & \\
\hline $\begin{array}{l}\text { After the restoration } \\
\text { of turgor }\end{array}$ & 581 & 1664 & 704 & 1.7 & 0,57 & 0.7 & & & 90.0 \\
\hline
\end{tabular}


Their leafy plate with wilting lost at least half of the total moisture content (39-46\%) and reduce the turgor in the range 83-100\%. Hardiness of photosynthetic structures in these cultivars was also high. In the cultivar Gavazuri parameter $\mathrm{F}_{\mathrm{v}} / \mathrm{F}_{0}$ as a result of dehydration decreased by $32 \%$. Behind him allocate cultivars Pintu, Veteran and Hidistavsky Belyiy. Change index $\mathrm{F}_{\mathrm{v}} / \mathrm{F}_{0}$ have been recorded within the $37-44 \%$.

It was noted that maintaining a high level of photoactivity of these cultivars was due to conservation a stable pool of light-harvesting complex $\left(\mathrm{F}_{\mathrm{m}}\right.$ and $\mathrm{F}_{\mathrm{v}} / \mathrm{F}_{\mathrm{m}}$ ) and reliable functioning of photochemical, "dark" processes the transformation of light energy (indicators $\left.\left(\mathrm{F}_{\mathrm{m}}-\mathrm{F}_{\mathrm{st}}\right) / \mathrm{F}_{\mathrm{m}}\right)$. On average, the suppression of these indicators in dehydration was 1.5-1.8 times less than in the group of resistant cultivars (Gavazuri, Pinto, Veteran and Hidistavsky Belyiy), compared with cultivars react more significantly to water deficit (Kryimsky Shedevr, Zempush).

It was noted that maintaining a high level of photoactivity of these cultivars was due to conservation a stable pool of light-harvesting complex $\left(\mathrm{F}_{\mathrm{m}}\right.$ and $\mathrm{F}_{\mathrm{v}} / \mathrm{F}_{\mathrm{m}}$ ) and reliable functioning of photochemical, "dark" processes the transformation of light energy (indicators $\left.\left(\mathrm{F}_{\mathrm{m}}-\mathrm{F}_{\mathrm{st}}\right) / \mathrm{F}_{\mathrm{m}}\right)$. On average, the suppression of these indicators in dehydration was 1.5-1.8 times less than in the group of resistant cultivars (Gavazuri, Pintu, Veteran and Hidistavsky Belyiy), compared with cultivars react more significantly to water deficit (Kryimsky Shedevr, Zempush).

Thus, the most favorable period for carrying out diagnostic measures for drought resistance (August, September), selected the cultivars of peach TszyuYus-Tszyuy, Gavazuri, Veteran, Hidistavsky Belyiy, combining high waterholding capacity with a stable maintenance of the level of functioning of the light-harvesting complexes. Changing the process of transformation of energy from the light-harvesting structures in pigment-protein complexes associated with the transmission and utilization of energy, quite objectively reflected in the dynamics of $\mathrm{F}_{\mathrm{v}} / \mathrm{F}_{0}$ and $\left(\mathrm{F}_{\mathrm{m}}-\mathrm{F}_{\mathrm{st}}\right) / \mathrm{F}_{\mathrm{m}}$.

On an indicator of $F_{v} / F_{0}$ the greatest value and, consequently, increased the proportion of photosynthetic active complexes recorded in cultivars Pintu, Gavazuri somewhat reduced, by about 5-8\% in cultivars Tszyu-Yus-Tszyuy and Veteran. Unstable cultivars have proven Zempush and BabyGold-7.

In the first measurement period (august) cultivar Hidistavsky Belyiy differed by good photosynthetic activity, increased water-holding capacity and reliable regenerative capacity. In the second measurement period (september) of this cultivar in the process of dehydration, decreased the amount of photosynthetically active forms and worsened water-holding capacity. At the same time reducing power remained at a high level.

Indicators $\mathrm{Fv} / \mathrm{F}_{0}$ and $\left(\mathrm{F}_{\mathrm{m}}-\mathrm{F}_{\mathrm{st}}\right) / \mathrm{F}_{\mathrm{m}}$ consistently characterize the state of the collection chain transfer and saving of the light energy depending on the degree of dehydration of leaf tissue. Still, allocated cultivars Pintu, Gavazuri and TszyuYus-Tszyuy. Their contribution to the preservation of photoactivity is $10-12 \%$ 
higher compared with other cultivars. Along with this they also have a high water-holding capacity and a significant degree of recovery turgidity of tissues $(82-100 \%)$.

The peachcultivars Hidistavsky Belyiy and Veteran are promising for further study of drought resistance. Some cultivars also have a high photoactivity at various stages of photosynthesis (Zempush, Baby Gold-7), indicating that the problems that exist in the interpretation of the mechanisms that determine the state of the photosynthetic apparatus in leaves dehydration.

\section{CONCLUSIONS}

The functional state of the photosynthetic apparatus of peach leaf depends on the cultivar characteristics and temperature. Three peach cultivars (Pintu, Gavazuri and Tszyu-Yus-Tszyuy) with a stable rate of photoactivity, high waterholding capacity and significant degree of recovery turgidity of tissues have been selected. These cultivars are interesting for breeding.

In general, it should be noted ample opportunity of fluorimetric method of analysis used for the isolation of promising cultivars of peach and their further use in breeding for economically valuable traits.

\section{ACKNOWLEDGMENT}

This study was funded by a research grant № 14-50-00079 of the Russian Science Foundation.

\section{REFERENCES}

Bilger W., Schreiber U. (1990).Chlorophyll luminescence as an indicator of stressinduced damage to the photosynthetic apparatus. Effects of heat-stress in isolated chloroplast.Photosynth.Res., 1990, 25 №3, pp. 161-171.

Brion O., Korneyev D., Snegur O., Kitayev O. (2000). Instrumental research of photosynthetic apparatus by means of chlorophyll fluorescence induction (Procedural Guidelines).Kiev, 2000.11 p.

Buschmann C. (1986) Fluoreszenz- und Wärmeabstrahlung bei Pflanzen - Anwendung in der Photosyntheseforschung.Naturwissenschaften 73: 691-699. [Fluorescence and heat dissipation in plants - application to the study of photosynthesis].

Ivashchenko Y.V. (2008). Asssesment of peach cultivars and forms by activity level oftheir photosynthetic apparatus: methodological aspects. Collection of scientific papers of the NBG-NSC, 2008.Vol. 129.pp. 57-70.

Kershanskaya O. (2007). Photosynthetic fundamentals of production process of wheat. Almaty, $2007.244 \mathrm{p}$.

Korneyev D. (2002). Information Capabilities of Chlorophyll Induction Technique. Kiev. Alterpres, 2002.188 p.

KrauseG., Weis E. (1991). Chlorophyll fluorescence and photosynthesis: the basics, Annu. Rev. Plant Physiol. Plant Mol. Biol. 42 (1991) 313-349.

Lichtenthaler H. (1992). The Kautsky effect: 60 years of chlorophyle fluorescence induction kinetics. Photosynthetica, 1992, Vol. 25, № 1-2, pp. 45-55.

LishchukA., Pilkevich R. (1999). The Field Technique for Assessment of Resistance to Drought and High Temperatures Intensification of Breeding of Fruit Crops: Collection of scientific papers. Yalta, 1999.Vol. 118. pp. 113-116. 
Physiological and biophysical techniques used in the breeding of fruit crops (Guidelines). Under edition of A.I. Lishchuk.Moscow, 1991. -67 p.

SmykovA., LukyanovaN., Ivashchenko Y. (2001). Assessment of feachures of photosynthetic apparatus in diagnostics of yielding capacity of fruit crops. Basic directions and techniques used in the breeding of pomaceous fruit grops: collection of scientific papers. Orel, 2001. pp. 88-89.

Stirbet A. (2011). On the relation between the Kautsky effect (chlorophyll a fluorescence induction) and Photosystem II: Basics and applications of the OJIP fluorescence transient, J. Photochem. Photobiol. B: Biol., 2011, pp. 1-22. 